\title{
Studies on the Microflora of Soil under Chronic Irradiation
}

\author{
By J. P. SKOU \\ Department of General Microbiology, Royal Veterinary and Agricultural College, \\ Copenhagen, and Agricultural Research Department, Danish Atomic Energy \\ Commission Research Establishment, Risö, Roskilde, Denmark*
}

(Received 18 September 1961)

SUMMARY

The number of micro-organisms present in soil located at a distance of $4 \mathrm{~cm}$. from a ${ }^{60} \mathrm{Co}$-source $1 \mathrm{~m}$. above ground declined considerably after $24 \mathrm{hr}$. of exposure. Respirometric determination showed no decrease in oxygen uptake at this time. The distance at which the effect of irradiation could be demonstrated increased with increasing duration of exposure; after 396 days a reduction of the oxygen uptake as well as of the number of microbes could be detected at a distance of more than $3 \mathrm{~m}$. and at a depth of $10 \mathrm{~cm}$. as well as at the surface.

There appeared to be no significant difference between the effects of chronic irradiation on spore-forming and on non-spore-forming bacteria, respectively.

The plot of microbial count showed a better fit to a double-logarithmic than to a semi-logarithmic diagram according to Lea's formula. Possible explanations of this fact are discussed.

\section{INTRODUCTION}

Few investigations have been conducted on the effect of extended periods of irradiation on micro-organisms in soil, although some contributions deal with the possibility of soil sterilization by irradiation. Dunn, Campbell, Fram \& Hutchins (1948) used X-rays and found that $100 \%$ inactivation of bacteria required between $5 \times 10^{5}$ and $10^{6}$ r. McLaren, Reshetko \& Huber (1957) studied enzymic activity in the soil under the influence of $\beta$-rays which, at the required levels of irradiation, seemed to cause less changes than the conventional methods of sterilization. Doses between 0.9 and $1 \cdot 1 \times 10^{6}$ r.e.p. inactivated all fungi and $1 \cdot 1$ to $2 \cdot 2 \times 10^{6}$ r.e.p. the bacteria of the soil as well. Stotzky \& Mortensen (1959) found no definite effect of $\gamma$-rays from a ${ }^{60} \mathrm{Co}$-source in doses of up to $250 \mathrm{krad}$. on the bacterial flora, while $8 \mathrm{krad}$. did reduce the number of fungi; this latter effect persisted after 54 days, probably due to competition from the rapidly multiplying bacteria rather than to the irradiation. Nitrification, ammonium formation and carbon dioxide production were not affected by irradiation. None of the authors make any statements concerning possible rules governing the inactivation of the populations studied, and it is doubtful whether sterility in the usual sense of the word was achieved. Platt \& Mohrbacher (1959) have planned an extensive programme of research concerned with the effects of radiation from an unprotected reactor on the macro- and microflora and -fauna in an area of 10,000 acres.

\footnotetext{
* Present address.
} 
The present study was designed to obtain a general picture of the effects of a ${ }^{60} \mathrm{Co}$-source on the microflora in adjacent soils, as expressed by oxygen uptake of soil samples and by counts of bacteria and fungi.

\section{METHODS}

Irradiation took place in an open-air gamma-field at Risö (Brynjolfsson \& Holm, 1960). The source consisted of ${ }^{60} \mathrm{Co}$ of a strength of 76 curies on 1 April 1959, producing $91 \mathrm{rad} . / \mathrm{hr}$. at a distance of $1 \mathrm{~m}$. at the beginning of the experiments. The final intensity at the conclusion of the experiments on 1 September 1960, was $76 \mathrm{rad} . / \mathrm{hr}$. at a distance of $1 \mathrm{~m}$. The calculated dose rate was checked by ferrous/ ferric dosimetry at varying distances.

An ordinary clayey soil was used for the experiments, the $\mathrm{pH}$ being $7 \cdot 4$, the humus content $2 \%$ and the water capacity $17 \%$. The soil was carefully mixed prior to laying out the experiments.

The present part of the study comprised the following two series.

Series 1. Aluminium cups were used; diameter $6 \mathrm{~cm}$., height $7 \mathrm{~cm}$., capacity $250 \mathrm{~g}$. soil. The samples were placed on a table at the following distances from the source: $0 \cdot 04,0 \cdot 125,0 \cdot 25,0.50,1 \cdot 00$ and $32 \cdot 25 \mathrm{~m}$. The distances were measured from the centre of the cups. The total amount of soil was analysed.

Series 2. Plastic tubes were used, diameter $35 \mathrm{~cm}$., depth $50 \mathrm{~cm}$., placed under the surface of the soil at the following distances from the source: $1 \cdot 12,1 \cdot 28,1 \cdot 57$, $2 \cdot 24,3 \cdot 15$ and $32 \cdot 25 \mathrm{~m}$. The distances were measured as in series 1 , but the sampling was made over an area of approximately $200 \mathrm{~cm} .{ }^{2}$ of the soil surface and at a depth of $10 \mathrm{~cm}$. The 'surface samples' were collected after removal of the upper $1-2 \mathrm{~cm}$. of soil which are continuously contaminated with micro-organisms from the surroundings.

Each dose measured refers to a point, and hence the unilateral radiation used for the present experiments makes it impossible to state the actual total dose. The relation between the calculated total doses, on the other hand, represents the true value. The results for the samples at a depth of $10 \mathrm{~cm}$. were referred to the doses calculated for the surface samples, since it proved impossible to determine the total doses at this depth due to the variations in the water content of the soil over extended periods as used here. In actual fact the curves for a depth of $10 \mathrm{~cm}$. should be transposed to a dose level which is lower by $25-40 \%$.

For series 1 samples were taken after 1, 2, 5 and 10 'days' and for series 2 after 71, 148, 266 and 396 'days'. A 'day' in this context is not synonymous with $24 \mathrm{hr}$. of radiation since for a few hours a day the gamma-field must be available for other studies. Thus the daily period of irradiation varied from $19 \cdot 6$ to $23 \cdot 6 \mathrm{hr}$. in series 1 and from 19.5 to $19.9 \mathrm{hr}$. in series 2.

On the basis of the above the total doses for individual samplings at different distances were calculated as listed in Table 1.

The microbiological activity was measured quantitatively by means of the oxygen uptake of the soil samples in a Warburg apparatus (Dixon, 1951; Umbreit, Burris \& Stauffer, 1957) and by counting of colonies of bacteria and fungi on agar plates, and qualitatively by examination of pure cultures at various distances from the source.

All respiration measurements were made in duplicate using accurately weighed 
samples each of about $2 \mathrm{~g}$. of soil. An addition of $1 \mathrm{ml}$. of $1 \%$ glucose was made at all measurements in series 1 and after 396 days of exposure in series 2, whereas the addition to the remaining samples was only $0.5 \mathrm{ml}$. of $1 \%$ glucose.

Table 1. Total doses in krad. received by the soil samples at different distances over different periods

\begin{tabular}{|c|c|c|c|c|c|c|c|}
\hline \multicolumn{3}{|c|}{ Duration of exposure } & \multicolumn{4}{|c|}{ Distance in $\mathrm{m}$. from ${ }^{\circ 0} \mathrm{Co}$-source } & \multirow[b]{2}{*}{$32 \cdot 25$} \\
\hline 'Days' & Hours & 0.04 & $0 \cdot 125$ & 0.25 & $\mathbf{0 . 5 0}$ & 1.00 & \\
\hline \multicolumn{8}{|c|}{ Series 1} \\
\hline $\mathbf{1}$ & $19 \cdot 6$ & 931 & 95 & 24 & 6 & $1 \cdot 5$ & 0 \\
\hline 2 & $47 \cdot 3$ & 2246 & 230 & 58 & 14 & $8 \cdot 6$ & 0 \\
\hline 5 & $106 \cdot 2$ & $\mathbf{5 0 4 4}$ & 517 & 129 & 32 & $8 \cdot 1$ & $\mathbf{0}$ \\
\hline \multirow[t]{3}{*}{10} & $213 \cdot 3$ & 10140 & 1038 & 259 & 65 & $16 \cdot 2$ & $\mathbf{0}$ \\
\hline & & \multicolumn{6}{|c|}{ Distance in $\mathrm{m}$. from ${ }^{\circ 0} \mathrm{Co}$-source } \\
\hline & & $1 \cdot 12$ & 1.28 & 1.57 & $\mathbf{2 \cdot 2 4}$ & $3 \cdot 15$ & $32 \cdot 25$ \\
\hline \multicolumn{8}{|c|}{ Series 2} \\
\hline 71 & 1412 & 101 & 77 & 51 & 25 & $12 \cdot 7$ & $0 \cdot 13$ \\
\hline 148 & 2919 & 205 & 157 & 104 & 51 & $26 \cdot 0$ & 0.25 \\
\hline 266 & 5220 & 359 & 275 & 183 & 90 & $45 \cdot 6$ & 0.43 \\
\hline 396 & 7719 & 519 & 397 & 264 & 130 & $65 \cdot 8$ & 0.63 \\
\hline
\end{tabular}

The bacteria were counted after plating on Difco nutrient agar $+0.5 \%$ glucose,

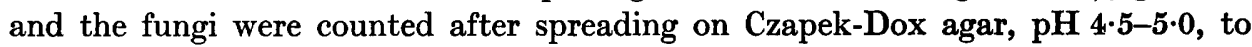
which had been added 2 p.p.m. of aureomycin. The soil was used directly as sampled from the gamma-field without drying and remoistening for the respiration measurements as well as for the counts; but in the case of each individual sample a dry-matter analysis was made on which was based the calculation of the results.

The suspension for the counts were prepared in the following way. After thorough mixing $10 \mathrm{~g}$. of soil was transferred to $0.5 \mathrm{l}$. Erlenmayer flasks containing $250 \mathrm{ml}$. of sterile salt solution according to Thornton $\left(5 \cdot 0 \mathrm{~g} . \mathrm{NaCl}, \mathbf{1} \cdot 0 \mathrm{~g} . \mathrm{MgSO}_{4} \cdot 7 \mathrm{H}_{2} \mathrm{O}\right.$, $1000 \mathrm{ml} . \mathrm{H}_{2} \mathrm{O}$ ), and the mixture was shaken mechanically for a period of $30 \mathrm{~min}$. Part of the resulting suspension was boiled for $5 \mathrm{~min}$. in order to destroy vegetative cells. The various dilutions used for the experiments with boiled and non-boiled soils were prepared from the suspensions which had been thus treated. The samples were incubated at $25^{\circ}$. Twelve repeats were made of each count.

\section{RESULTS}

The chief results of the respiration experiments are found in Table 2, in which the samples below the dotted lines, i.e. the samples which are approximately $10 \%$ lower than the control, are considered to show the effect with certainty.

A 1-day exposure produced only a very faint effect on the oxygen uptake at a distance of $4 \mathrm{~cm}$. After 10 days of exposure it was not yet possible to demonstrate any effect at a distance of $50 \mathrm{~cm}$. The table shows the spreading effect for 396 days when it could be detected at a distance of a good $3 \mathrm{~m}$. from the source at the surface as well as at a depth of $10 \mathrm{~cm}$. In the case of the shortest period of exposure the respiration curves are close together, but with increasing duration of the 
exposure the samples closest to the source branch off and spread downwards, fanshaped, the control remaining virtually constant. The first hours of respiration after 10 days of exposure in the series 1 samples may be seen from Fig. 1 .

The results of the counts of bacteria and fungi may be seen in Figs. 2 and 3. The number of micro-organisms was not particularly high compared to that often found in soil, and there was no particular difference between the number found at the surface of the soil and that at a depth of $10 \mathrm{~cm}$. There was a strong seasonal variation in the number of bacteria. Hence in the case of series 2 only a comparison of the course of the curves is possible.

Table 2. Total uptake of oxygen per g. dry soil after $10 \mathrm{hr}$. respiration

The samples below the dotted lines drawn are considered to show the effect of irradiation with certainty.

\begin{tabular}{|c|c|c|c|c|c|c|c|c|c|c|c|c|}
\hline \multirow{4}{*}{$\begin{array}{l}\text { Duration of } \\
\text { irradiation } \\
\text { 'days' }\end{array}$} & $\mu \mathrm{l} . \mathrm{O}_{2}$ & $\begin{array}{c}\text { Relative } \\
\text { value }\end{array}$ & $\mu \mathrm{l} . \mathrm{O}_{\mathrm{s}}$ & $\begin{array}{c}\text { Relative } \\
\text { value }\end{array}$ & $\mu \mathrm{l} . \mathrm{O}_{2}$ & $\begin{array}{c}\text { Relative } \\
\text { value }\end{array}$ & $\mu \mathrm{l} . \mathrm{O}_{\mathrm{s}}$ & $\begin{array}{c}\text { Relative } \\
\text { value }\end{array}$ & $\mu \mathrm{l} . \mathrm{O}_{\mathbf{2}}$ & $\begin{array}{c}\text { Relative } \\
\text { value }\end{array}$ & $\mu \mathrm{l} . \mathrm{O}_{\mathrm{a}}$ & $\begin{array}{c}\text { Relative } \\
\text { value }\end{array}$ \\
\hline & \multicolumn{12}{|c|}{ Distance from ${ }^{\circ{ }^{\circ} \mathrm{Co}-\text { source }(\mathrm{m} .)}$} \\
\hline & \multirow{2}{*}{\multicolumn{2}{|c|}{0.04}} & \multicolumn{2}{|c|}{0.125} & \multicolumn{2}{|c|}{0.25} & \multicolumn{2}{|c|}{0.50} & \multicolumn{2}{|c|}{1.00} & \multicolumn{2}{|c|}{$32 \cdot 25$} \\
\hline & & & & & & ries 1 & & & & & & \\
\hline 1 & 67 & 92 & 78 & 107 & 81 & 111 & 71 & 98 & 79 & 109 & 72 & 100 \\
\hline 2 & 66 & 76 & 73 & 84 & 76 & $87:$ & 80 & 92 & 82 & 94 & 87 & 100 \\
\hline 5 & 54 & 77 & 59 & 85 & 66 & 94 & 72 & 103 & 73 & 104 & 70 & 100 \\
\hline \multirow[t]{4}{*}{10} & 39 & 52 & 49 & 65 & 51 & 68 & 72 & 95 & 71 & 94 & 75 & 100 \\
\hline & \multicolumn{12}{|c|}{ Distance from ${ }^{\circ 0} \mathrm{Co}$-source $(\mathrm{m})}$. \\
\hline & \multicolumn{2}{|c|}{$1 \cdot 12$} & \multicolumn{2}{|c|}{1.28} & \multicolumn{2}{|c|}{1.57} & \multicolumn{2}{|c|}{$2 \cdot 24$} & & \multicolumn{2}{|c|}{$32 \cdot 25$} \\
\hline & & & & & \multicolumn{4}{|c|}{ Series 2, soil 'surface' } & \multicolumn{2}{|c|}{ 3.15 } & \multicolumn{2}{|c|}{0200} \\
\hline 71 & 36 & 84 & 34 & 80 & 38 & 89 & 43 & 100 & - & - & 43 & 100 \\
\hline 148 & 27 & 75 & 24 & 66 & 23 & 64 & 25 & 71 & 34 & 96 & 36 & 100 \\
\hline 266 & 32 & 79 & 30 & 73 & 31 & 77 & 34 & 84 & 37 & 89 & 41 & 100 \\
\hline 396 & 57 & 71 & 58 & 73 & 55 & 69 & 74 & 93 & 72 & 91 & 80 & 100 \\
\hline \multicolumn{13}{|c|}{ Series 2, depth $10 \mathrm{~cm}$. } \\
\hline 71 & 38 & 76 & 35 & 70 & 44 & $89 !$ & 48 & 97 & 48 & 96 & 49 & 100 \\
\hline 148 & 21 & 62 & 19 & 58 & 32 & 97 & 32 & 97 & 29 & 88 & 33 & 100 \\
\hline 266 & 25 & 80 & 26 & 82 & 26 & 84 & 32 & 100 & 32 & 100 & 32 & 100 \\
\hline 396 & 40 & 52 & 46 & 60 & 48 & 63 & 60 & 78 & 64 & 83 & 77 & 100 \\
\hline
\end{tabular}

In Fig. 2 the results of series 1 are recorded on a semilogarithmic scale, the numbers of bacteria and fungi being related to the time of exposure which is used as an indication of the dose. After 10 days of exposure the bacteria were affected at a distance of up to $1.0 \mathrm{~m}$., and the fungi up to $0.5 \mathrm{~m}$. At a distance of $4 \mathrm{~cm}$. the number of bacteria was so low and uncertain at exposures of 5 and 10 days that the data do not lend themselves to statistical treatment, whereas a certain amount of fungus growth remained at these durations.

Figure 3 shows the results from series 2. After a period of 71 days the effect could be detected at the surface closest to the source $(1.12 \mathrm{~m}$.) in boiled as well as in nonboiled soil samples. The effect could be traced at increasing distances with increasing duration of the exposure; after 396 days it could be detected at a distance of a good $3 \mathrm{~m}$. in all cases, which is in good agreement with the respiration studies.

Although the $5 \mathrm{~min}$. of boiling reduced the number of bacteria in the soil to approximately $1 \%$ of its initial value, the course of the curves remains the same. Hence surprisingly the spore-forming bacteria appear to be no more resistant to the chronic irradiation than are the non-spore-forming ones. 


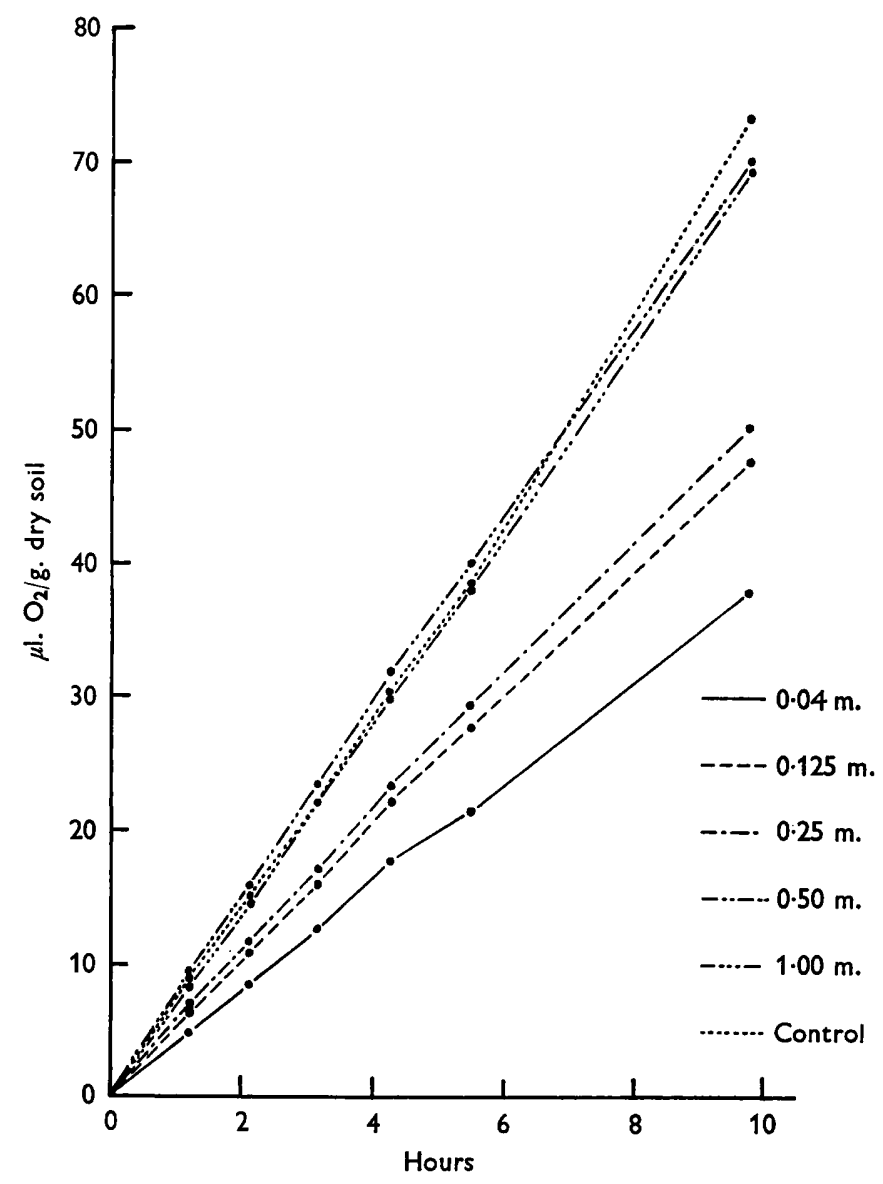

Fig. 1. The first hours of oxygen uptake at different distances from the source after 10 days of exposure in series 1 .
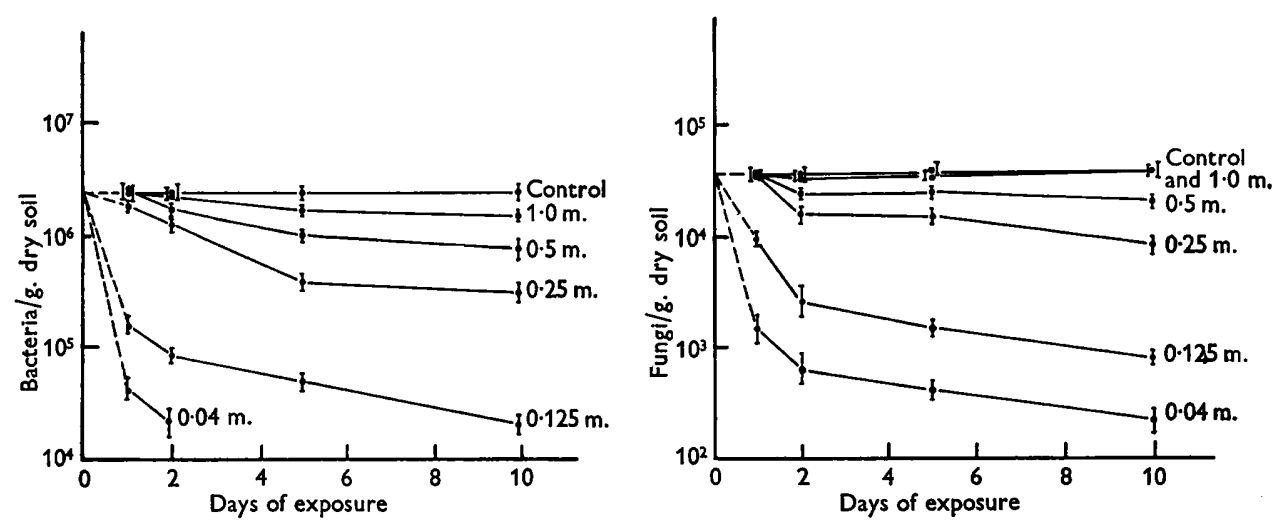

Fig. 2. Numbers of bacteria and fungi at different distances from the source in series 1 . 
The curves also show that the difference between the effect at the surface and at a depth of $10 \mathrm{~cm}$. is but slight.

In connexion with series 2 a study was made of the following 15 pure cultures in
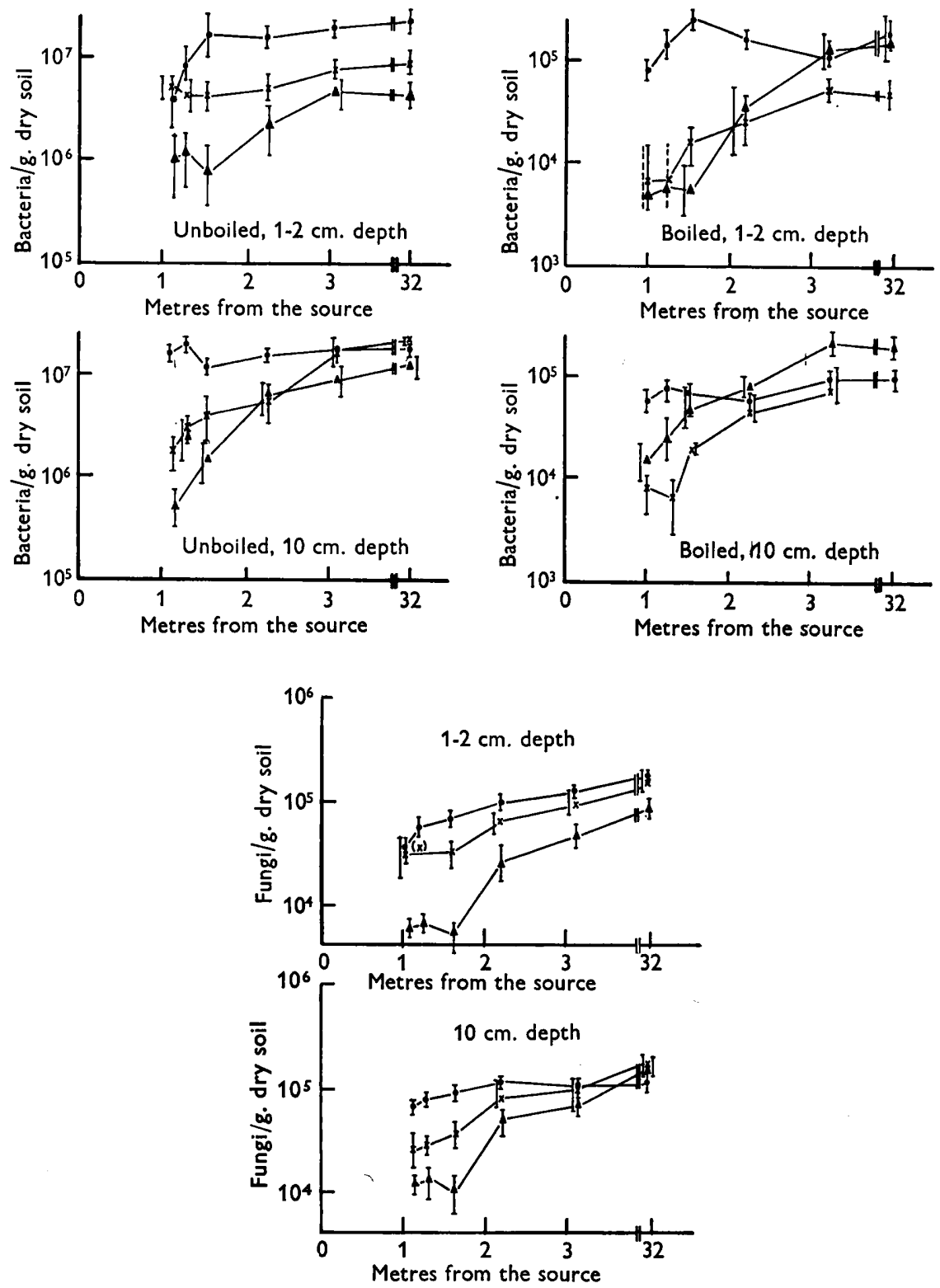

Fig. 3. Number of bacteria and fungi at different distances from the source in series 2. , 71 days of exposure; $\times, 266$ days of exposure, $\Delta, 396$ days of exposure.

sterile garden soil: Pseudomonas fuorescens Migula, Bacillus subtilis Cohn, B. megaterium de Bary, Clostridium bifermentans (Weinberg \& Seguin) Bergey, Azotobacter chroococcum Beijerinck (3 cultures), Rhizobium meliloti Dangeard (contaminated 
after 266 days), Corynebacterium sp. (isolated from soil), Mycobacterium sp. (isolated from soil), Nocardia corallina (Bergey) Waksman \& Henrici, Streptomyces griseus (Krainsky) Waksman \& Henrici, Rhizopus nigricans Ehrenberg, Penicillium notatum Westling, Cladosporium herbarum (Pers.) Link. Twelve of these 15 cultures remained alive at all distances after 396 days of exposure; only the 3 cultures of Azotobacter chroococcum had died at distances from 1.28 to $1.57 \mathrm{~m}$.

The spore-forming bacteria, the Phycomycetes and the yeasts proved to be the most resistant species at brief exposures closest to the source, whereas the nonspore-forming bacteria and the Aspergillus and Penicillium species were obviously more sensitive.

\section{DISCUSSION}

For both series, the reduction in uptake of oxygen is considerably lower than the reduction which might be expected to result from the reduction in the number of micro-organisms. The difference is most pronounced in the case of series 1 . This is probably due to the enzymic activity in the soil, since the enzymes in general are not affected nearly as much as the micro-organisms (see, for example, Billen, Stapleton \& Hollaender (1953), Siu (1957), and McLaren et al. (1957)).

A number of authors have studied the laws governing the inactivation of pure cultures by irradiation, but only few have related these problems to natural populations. Davis, Sheldon \& Auerbach (1956) studied a natural population from a hollow in a beech tree and found it impossible to compute LD 50 values or regression lines for the curves because the population caused too great deviations from Lea's formula of $N=N_{0} e^{-k D}$ (Lea, 1955) which is valid in a number of cases of irradiation of pure cultures. The authors consider this to be due to the fact that each segment of the population is inactivated at its own specific rate.

Halkier (1959, 1960), working with various pure cultures of bacteria isolated from fish, found his results to agree better with the following formula than with that of Lea's:

$$
\frac{N}{N_{0}}=\left(\frac{D}{D_{0}}\right)^{-a}
$$

which converted to the logarithmic form becomes $\log N=k-a \log D^{\prime}, N_{0}$ being the number of organisms in untreated cultures, $D_{0}$ being the highest dose at which the number of organisms is still $N_{0}, N$ being the number of organisms producing visible colonies at the dose $D . a$ is a non-dimensional gradient. $D^{\prime}=D / D_{0}$; defined for $D^{\prime} \geqslant 1$. For $D^{\prime}<1, N / N_{0}=1$. From $D^{\prime}=1$ the formula gives a straight line on a double logarithmic plot.

This formula gave much better agreement than did Lea's when used on the present data. The results from series 1 are seen in Fig. 4 in which each dotted line refers to a specific distance and each plot represents a sampling.

For bacteria as well as for fungi there is a minimum effective dose corresponding to $D_{0}$, and for each distance the inactivation appears to follow a straight line. However, the author dare not postulate that the lines are straight as there is frequently significance at the $95 \%$ level. In spite of the variations the corresponding curves from series 2 give the same picture. Examples may be seen in Fig. 5.

When used for the same formula the data of McLaren et al. (1957), and of Stotzky \& Mortensen (1959) prove to be excellently suited for double-logarithmic plotting, 
whereas the data of Dunn et al. (1948) show a better fit to plotting according to Lea's formula.

Recently Etchells, Costilon, Bell \& Rutherford (1961) have published a work on irradiation of microbes from cucumber fruits and blossoms. For all the seven groups
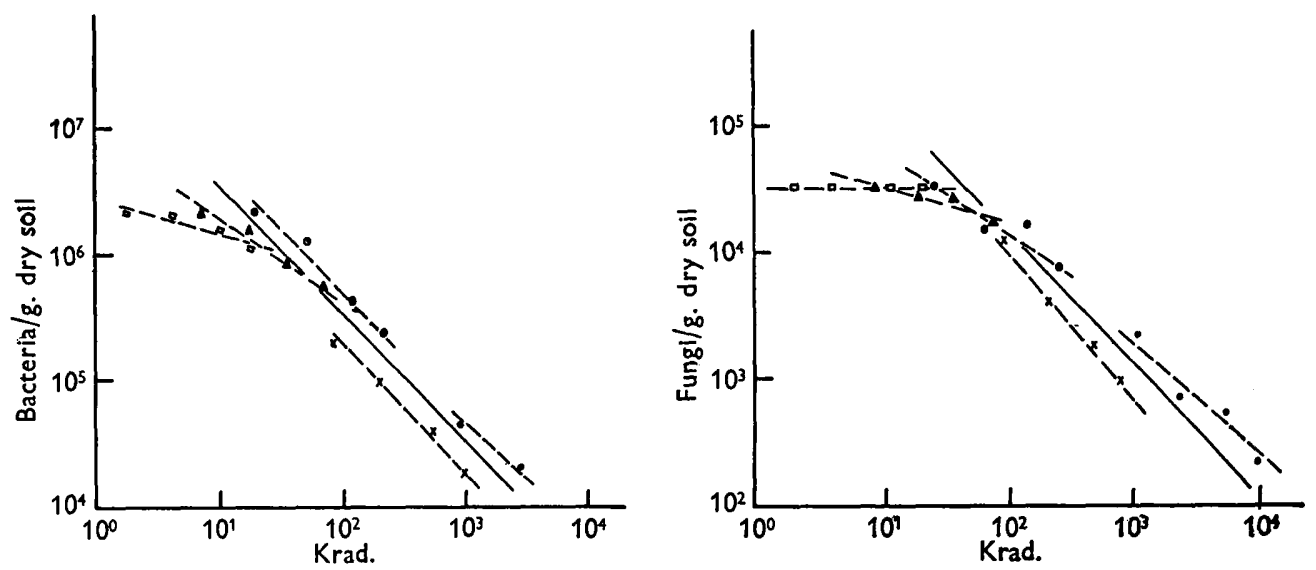

Fig. 4. The number of bacteria and fungi from series 1 in double-logarithmic diagram. $0,0.04 \mathrm{~m}$. (47.5 krad./hr.); $\times, 0.125 \mathrm{~m}$. (4.86 krad./hr.); $\odot, 0.25 \mathrm{~m}$. (1.22 krad./hr.); $\Lambda, 0.50 \mathrm{~m}$. (0.30 krad./hr.); $\square, 1.00 \mathrm{~m}$. (0.076 krad./hr.).

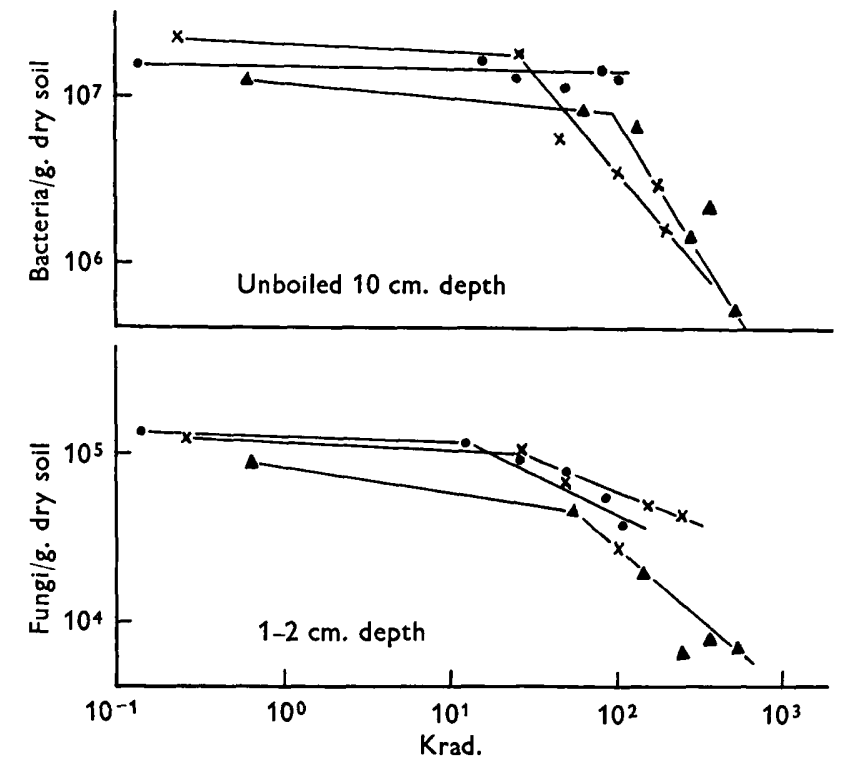

Fig. 5. Examples from series 2 of the number of bacteria and fungi in double-logarithmic diagram., 71 days of exposure; $\times, 266$ days of exposure; $\triangle 396$ days of exposure.

of organisms tested the results will give a straight or nearly straight line in a doublelogarithmic plot.

These results support Davis's theory of each organism (segment) of the population 
producing a characteristic curve of its own. Highly sensitive organisms exercise their greatest influence on the sum-curve of the population during its initial course; subsequently the more resistant species grow in influence, and finally the most resistant species become those which chiefly determine the shape of the sum-curve.

If Lea's formula is suitable for a majority of the species in a natural population, then the shape of the sum-curve for a natural population of wide spectrum such as found in the soil approaches or gives a straight line on a double-logarithmic plot, but if the spectrum of the population is not sufficiently wide, curves with one or more bends may result, and if a few species of different sensitivities constitute the majority of the population, the curve will not fit either of the formulae.

Lea's formula produces no $D_{0}$-value, but in many cases sigmoid curves have resulted from the use of this formula (the multi target theory, Lea, 1955, and extrapolation number, Alper, Gilles \& Elkind, 1960), thus increasing the probability of a direct connexion between the two formulae.

Hence the conclusion is drawn that the same laws apply to irradiation of natural populations and to irradiation of pure cultures, only the results are depicted differently, because in the case of the natural populations the curve is a sum-curve.

As the two series are in accordance on a double-logarithmic plot (i.e. identical at high and low dose rates), it appears to be probable that the effect of the microorganisms may be accumulated in such a way that the effect becomes apparent only after a few generations. An inhibition of the reproduction of $0 \cdot 1-1 \cdot 0 \%$ of the value required to maintain the population may not be noticeable in one individual generation, but nevertheless it may cause a considerable reduction of the number in the course of a few generations.

The author is particularly indebted to Professor Erik J. Petersen of the Department of General Microbiology, Royal Veterinary and Agricultural College, under whose guidance the present work was carried out. Samples were irradiated at the Danish AEC Research Establishment, Risö, where part of the laboratory work was also done, and I am indebted to this institution for favourable working conditions and for the use of laboratories and facilities. Finally my thanks are due to Mr J. E. Maul, civil engineer, for help with the dosimetry.

\section{REFERENCES}

Alper, T., Gilles, N. E. \& Elkind, M. M. (1960). The sigmoid survival curve in radiobiology. Nature, Lond. 186, 1062.

Billen, D., Stapleton, G. E. \& Hollaender, A. (1953). The effect of X-radiation on the respiration of Escherichia coli. J. Bact. 65, 131.

Brynjolfsson, A. \& Holm, N. W. (1960). The $\mathrm{Co}^{60}$ irradiation facility and the gamma field at Risö. Large Radiation Source in Industry, p. 115. Vienna: IAEA.

Davis, R. J., Sheldon, V. L. \& Auerbach, S. J. (1956). Lethal effects of gamma radiation upon segments of a natural microbial population. J. Bact. 72, 505.

Drxon, M. (1951). Manometric Methods as Applied to the Measurement of Cell Respiration and other Processes, 3rd edn. Cambridge University Press.

Dunn, C. G., Campbell, W. K., Fram, H. \& Hutchins, A. (1948). Biological and photochemical effects of high energy, electrically produced roentgen rays and cathode rays. J. appl. Phys. 19, 605.

Etchells, J. L., Costilon, R. N., Bell, T. A. \& Rutherford, H. A. (1961). Influence of gamma-radiation on the microflora of cucumber fruit and blossoms. Appl. Microbiol. 72,145 . 
HALKIER, S. B. (1959). Strålekonservering af fisk. Levnedsmiddelkonservering ved bestråling, p. 69. Only in Danish.

Halkier, S. B. (1960). The effect of $\mathrm{Co}^{60}$ irradiation on bacteria from fish. Risö Report, no. 16, p. 44.

LEA, D. E. (1955). Action of Radiation on Living Cells, 2nd edn. Cambridge University Press.

Mclaren, A. D., Reshetko, L. \& Huber, W. (1957). Sterilization of soil by irradiation with an electron beam, and some observations on soil enzyme activity. Soil Sci. 83, 497.

Platt, R. B. \& Mohrbacher, J. A. (1959). Studies in radiation ecology. I. The program of study. Bull. Georgia Acad. Sci. 17, 1.

Siu, R. G. H. (1957). Action of ionizing radiation on enzymes. The U.S. Army Quartermaster Corps : Radiation Preservation of Food, p. 169. Washington D.C.: U. S. Government Printing Office.

Stotzky, G. \& Mortensen, J. L. (1959). Effect of gamma radiation on growth and metabolism of microorganisms in an organic soil. Proc. Soil Sci. Soc. Amer. 23, 125.

Umbreit, W. W., Burris, R. H. \& Stauffer, J. F. (1957). Manometric Techniques. Minneapolis: Burgess Publishing Co. 